\title{
The English Teachers' Management for The Preparation in Teaching and Learning Process of Genre - Based Writing Instruction in 2013 Curriculum at Senior High School in Pesisir Selatan Regency
}

\author{
Yuni Cenrikawaty $^{1}$, Mukhaiyar ${ }^{2}$, Anas Yasin ${ }^{3}$, and Ngusman Abdul Manaf ${ }^{4}$ \\ University of Padang, Padang West Sumatera, Indonesia \\ yunicenrikawaty1973@gmail.com
}

\begin{abstract}
This research is based on some problems faced most of senior high school students in Pesisir Selatan Regency in English writing, especially in writing kinds of genre based on the 2013 curriculum; the students get poor performance in English writing. The research aims to know how the English teachers prepare the the lesson plan, the teaching aids or media and the English writing material in helping the students learn English writing skill as suggested by genre - based writing instruction in the 2013 curriculum. The kind of this research is a qualitative evaluation with ethnography method. The data are mostly gained from the classroom analysis done through observation supported by field notes and videotaping, interview and document analysis. The subjects of this research were English teachers from six senior high schools that had implemented the 2013 curriculum in Pesisir Selatan Regency. The result shows that; firstly mostly the English teachers had prepared the lesson plan in helping the students learn English writing skill as suggested by genre - based writing instruction in the 2013 curriculum, nevertheless some English teachers'lesson plan hadn't based on process standard as stated at the minister of national education regulation no 22 year 2016 in the 2013 curriculum. It proved that the document analysis result of some English teachers' lesson plans got bad quality. Secondly, mostly English teachers hadn't prepared the teaching aids or media in helping the students learn English writing skill as suggested by genre - based writing instruction in the 2013 curriculum, so that they seldom used the teaching aids or media in their learning process of writing skill. Thirdly, mostly English teachers had prepared the English writing materials, the English text books. Nevertheless, it is only adapted from the English text books or ready use books, most of them seldom create English writing materials by her/his self ; English module or diktat. Based on the data analysis, the researcher concludes that the English teachers' management for the preparation in teaching and learning process of genre - based writing instruction in 2013 curriculum at senior high school in Pesisir Selatan Regency has not been managed by the English teachers optimally.
\end{abstract}

Keywords - Genre-Based Writing Instruction, the lesson plan, the teaching aids and learning material

\section{INTRODUCTION}

Teaching writing for EFL learners is challenging as what Kim and Kim (2005:68) argue, EFL learners mostly face "time constraints in learning writing," so do Indonesian learners. Alwasilah (2001:25) found in his research that writing practices in EFL classrooms in Indonesia were only on "spelling, word formation, vocabulary, grammar, and theories about writing"which disregarded the context, students' needs, and goals. It 
was also informed that writing session in the classroom consisted of very few acts of writing, saying that "practice of writing does take place in the class, yet it contributes almost nothing to the build-up of writing skills". Therefore, to promote a better writing activity in the classroom, teachers are required to choose approaches which can accommodate time, students' vocabulary, grammar, and theories about writing"which disregarded the context, students' needs, and goals. It was also informed that writing session in the classroom consisted of very few acts of writing, saying that "practice of writing does take place in the class, yet it contributes almost

\author{
${ }^{1}$ Education Science Study Program of Doctoral Program of Post Graduate Program, State University of Padang \\ on 2010 \\ 2 Faculty of Language Teaching Program and Arts, State University of Padang, Indonesia \\ ${ }^{3}$ Faculty of Language Teaching Program and Arts, State University of Padang, Indonesia \\ 4 \\ Faculty of Language Teaching Program and Arts, State University of Padang, Indonesia
}

nothing to the build-up of writing skills". Therefore, to promote a better writing activity in the classroom, teachers are required to choose approaches which can accommodate time, students' needs, and the practice. There are approaches to teaching writing with distinct goals and steps for each, one of them, genre-based approach (Halliday, 1994).

Therefore, an assigned genre seems to serve as an influential tool for both the learning and teaching of writing for both students and teachers. Hyland (2004:10-11) sees the advantages of a genre based writing instruction that can be summarized as follows: first, explicit, this makes clear what is to be learned to facilitate the acquisition of writing skills. Second, systematic, this provides a coherent framework for focusing on both language and contexts Needs-based. Third, ensures, it is course objectives and content are derived from students needs. Fourth, supportive, it gives teacher a central role in scaffolding student learning and creativity. Fifth, empowering provides, it access to the patterns and possibilities of variation in valued texts. Sixth, critical, it provides the resources for students to understand and challenge valued discourses. Finally, consciousness rising, It increases teacher awareness of texts and confidently advise students on their writing.

Despite genres' beneficial roles in helping learners to produce written work with confidence, there are two concerns about the genre approach. One is that it underestimates the skills required to produce content, and the other concern is that it neglects learners' self-sufficiency Byram ( 2004:236). The genre approach not only places too much emphasis on conventions and genre features but also is less helpful for students in discovering the texts' true messages due to the targeted aspects of the specified genre. Likewise, if teachers spend class time explaining how language is used for a range of purposes and with a variety of readers, learners are likely to be largely passive. Thus, the genre approach is blamed for limiting learners' creative thoughts about content and is criticized in that it overlooks natural processes of learning and learners' creativity Badge \& White (2000:157). Finally, Bawarshi (2000:343) pointed out that, at its best, it helps learners to identify and interpret literary texts, while at its worst, it interferes with the learners' creativity.

Nevertheless, the Indonesia students usually find some difficulties when they are learning about genre and its writing. They cannot sit quietly and pay full attention during the lesson without doing anything, because writing skill is a hardest skill to master, because the ability to write in foreign language is more complicated than the ability to speak, read, or listen. It is hard to teach students how to write because it involves many components such as structure, vocabulary, punctuation, and spelling.

Then, writing is sometimes seen as the "flip side" of reading. It is often assumed that the students who are proficient readers must be proficient writers, too. If this was the case, then helping students learn to read better would naturally lead to the same students writing well. However, although reading and writing are complementary skills whose development runs a roughly parallel course, they do not necessarily go hand in hand. Many students are able to handle average reading demands but have severe difficulties with writing. Whereas, a wide range of jobs require employees to produce written documentation, visual or text presentations, memoranda, technical reports, and electronic messages in English. The explosion of electronic and wireless communication in everyday life brings writing skills into play as never before. The demand for writing proficiency is not limited to professional jobs but extends to clerical and support positions in government, construction, manufacturing, service industries, and elsewhere.

More ever, education policy for English language teaching in Indonesia has undergone several changes. The changing aims at improving the outcomes of English language teaching itself. This connects with Undang Undang RI, No 20 year 2003 which emphasizes that the system of national education has to be guarantee equality in education opportunity, quality improvement, and relevance and efficiency of educational management to equip 
the citizens to overcome challenges locally, nationally, or internationally and in addition to an educational reform which is well-organized, focus and sustainable is needed in terms of educational system, curricula, learning materials, teaching and learning strategies, as well as teaching learning approach.

Regarding the need for educational reform, a good quality of education, is basically determined adequate and appropriate approach model in teaching learning process. The more effective approach model in teaching learning process, the better the quality of the education will be. More ever in order to the national educational purpose can be reached, teaching and learning process should guide of national standard that stated at the minister regulation of national education No 22 year 2016 on Process Standard for education unity of elementary school until education Unity of High School states that: teaching and learning process of education unity of elementary school until education unity of high school is done interactively, inspiration, enjoyably, challenge, and encouraging students' motivation to participate actively, and also give enough chance to be creatively and stand for by themselves appropriate with talent, motivation and development of students physic and physicist.

Therefore, the English teachers had to manage the proper preparation in teaching and learning process to help students learn English writing skill in the 2013 curriculum, such as; the lesson plan, the media and the English writing material. So that, the teaching and learning process can be conducted interactively, inspiration, enjoyably, challenge, and encouraging students' motivation to participate actively and also give enough chance to be creatively and stand for by themselves appropriate with talent, motivation and development of students physic and physicist. In other word, the English teachers should consider some preparations before conducting the teaching and learning process; they are core competency and basic competence should be defined specifically, clear defined of syllabus, the preparation of teaching or lesson plan should be well prepared before coming to the class, the practical, compatible, useful English writing materials and using various media. Without the preparation of teaching that was planned, such as the lesson plan, the media and the English writing material, so the teaching and learning process of genre - based writing instruction would not be conducted effectively.

\section{THEORITICAL REVIEW}

\subsection{Genre -Based writing Instruction}

\subsubsection{The concept of writing skill}

It can be said that writing is a crucial part in our global society. Writing has many general concepts. There are several definitions of writing that can be stated as follows: Among the four skills (listening, speaking, reading and writing), writing is often considered as the most difficult skill because it combines the thought and activity. This activity needs a process. According to Hedge (2000:302) states that writing is the result of employing strategies to manage the composing process, which is one gradually developing a text. It can be said that one is writing if he employs three major aspects conceived in writing (the employment of grammatical rules of the language, the employment of appropriate lexical items, and the employment of the rhetorical patterns of writing) at once.

Pertaining to the complexities of writing, it involves a number of activities: setting goal, generating ideas, organizing information, selecting appropriate language, making a draft, reading and reviewing it, then revising and editing. In relation the theory the writer can conclude that writing is a complex process which is neither easy nor spontaneous for many second languages.

\subsubsection{The definition of Genre}

The term genre was firstly introduced by Elaine Tarone in 1981. It has been applied in three areas of studies i.e. ESP (English for Specific Purpose), new rhetoric and (Systemic Functional Grammar). Genre in Language teaching is closely related to SPL area in area in which this theory describes language in terms of the choices a speaker or writer makes from the system in particular contexts of use (Paltridge, 2001: 6). In language teaching, genre derived from the Australian elementary-school classroom. In Indonesia, genre is used since curriculum in 2006 and continued on new curriculum in 2013.

In addition to, Swales (1990: 58) identified a genre as "a class of communicative events, the members of which share some set of communicative purposes". His definition offers the basic idea that there are certain conventions or rules which are generally associated with a writer's purpose. For example, personal letters tell us about their writers' private stories, film reviews analyze movies for potential viewers and police reports describe what happened. Most genres use conventions related to communicative purposes; a personal letter starts with a cordial question in a friendly mood because its purpose is to maintain good relationships with friends, and an argument essay emphasizes it's thesis since it aims at making an argument.

\subsubsection{Types of Genre}


The term 'genre' describes types of activities such as, for example, prayers, sermons, songs, and poems, 'which regularly occur in society' (Dudley-Evans 1998: 77), and 'are considered by the speech community as being of the same type' (Richards et al. 1992:156). In addition to, Gerot and wignell (1995) compile kinds of genre in a different form namely, exposition (analytical), anecdote, report, exposition, narrative, discussion, new item, procedure, explanation, and review description. They then divide those text types into technical and humanities. The technical genres are such as argument; metalwork, report; and so on which related to technical work or workshop. The humanities genres are like narrative, biography, historical recount, report/descriptive, factorial explanation and argument. The following are the characteristics of each genre (Gerot and wignell, 1995);narrative, biographical recount,historical,factual report, descriptive and argumentation.

\subsection{The Concept of the Lesson Plan}

\subsubsection{The Definition of the Lesson Plan}

As Brown (2001: 149) said that the word lesson plan is popularly considered to be a unified set of tasks that cover a period of classroom time, usually ranging from forty to eighty minutes. These classroom time units are administratively significant for teachers because they represent "steps" along a curriculum before which and after which teachers have a hiatus (of a day or more) to evaluate and prepare for the next lesson, also he affirms that those lessons, from the point of view of teachers and students' time management are practical, tangible units of effort that serve to provide a rhythm to a course of study. In other words, what Brown affirms is that a lesson is a proposal for action rather than a blueprint to be followed slavishly. And once teachers put their proposal for action into action, all sorts of things might happen, quite a few of which we might not have anticipated.

Whereas Rinvolucri (1996: 7) states that a lesson plan is a mental structure or the map teachers need initially to help them through the landscape. And students, too, like to know what their teacher has in store for them. Evidence of teacher planning helps to ensure their confidence in the person who is teaching them.

Then Syllabus is a lesson plan in specific subject group that covered core competence, basic competence, instructional material, indicator, scoring, time allocation, and source of learning that developed in education unity. The English writing syllabus for the senior high school grade is National syllabus in the curriculum of 2013 as stated at the Minister of National Education Regulation No 21 year 2016 about content standard and it is also stated at the Minister of National Education Regulation No 24 year 2016 about the core competence and basic standard.

\subsubsection{Proposed Genre- Based Lesson Plan for Writing skill}

A process-genre approach (PGA) was then developed by some experts (see Badger \& White, 2000; Yan, 2005; Lee, et al. 2009). Practically, PGA incorporates the four teaching steps of genre-based approach, in which process based writing occurs in the latter two steps as explained in the following.

\subsubsection{Building knowledge of the field (BKOF)}

All activities are aimed at defining situation that will be used as the topic and place it within a particular genre has also been implemented through brainstorming stage in process -based approach. Furthermore, this stage prepares the students to anticipate the structural features of the genre from variation of relevant texts (Yan, 2005). Students need to know what the topic under discussion is because people have to know the specific topic they want to write Emilia (2008 : 25). Additionally, Emilia informs that in BKOF students can also practice other language skills relevant to the topic such as giving a listening test to fill in spaces in a paragraph containing specific words in the genre, exercising reading comprehension, and expressing ideas orally can be conducted to familiarize students with the topic in context Emilia (2012 : 35-41). In other words, students are introduced to wide variation of reading passages of the genre in order for them to know exactly the specific languages used in the text type. Moreover, students can be introduced to the creation of writing plan in the form of mind-mapping or outlines from the sample texts as their guidance to individual writing.

\subsubsection{Modelling}

Modelling stage is meant to give students in-depth information about the text type they are learning through the "stages of the genre and its key grammatical and rhetorical features" Hyland ( 2007 : 132). The provision of varied text sources of the genre for students are aimed at getting them to understand how the organization of the text (schematic structure) is developed to accomplish the purpose (Yan, 2005) and also the linguistic features of the genre. Furthermore, explicit and bilingual teaching in this stage are tangible (Hammond, 1990) because this stage deals with technical learning materials of the genre such as 
schematic structure and linguistic features that are needed to be taught in both native and target languages (Emilia, 2012).

\subsubsection{Joint construction of text (JCoT)}

As stated before hand, JCoT implements the writing practice as in process-based approach where students, either in groups or by teacher's guidance, create their first writing model together. According to Yan (2005), the goal of this stage is "to produce a final draft which provides a model for students to refer to when they work on their individual compositions"in independent construction stage. Students can also do the first step again to activate their prior knowledge to the topic and plan what things they are going to write by brainstorming the ideas. After producing joint-writing products, students are introduced to feedback towards their writing (Emilia, 2010; 2012). This is aimed at familiarizing students with the writing process that many great writers usually go through. Peer-feedback and teacher-feedback are required in this stage to bridge the revision stage occurred in JCoT.

\subsubsection{Independent construction of text (ICoT)}

Students write individually through guidance provided by the teachers. Teachers can decide the topic or students can choose freely the topic that is still relevant to the genre. Similar to genre-based approach, teachers' control is decreasing since students start to apply what they have learned (Hyland, 2007) but the teacher is available to help, clarify, or consult the process of writing. In other words, independent construction produces drafts. Students will go through again the revision and conference from peers and teacher. Revising stage is crucial because this requires students to be an active reader and proof-reader of their writing as well as their peers' writing drafts. As mentioned by Badger and White (2000), drafting process is the main focus in this stage. Students are practised to the recurring writing process after producing their draft.

\subsection{The Concept of the Instructional Media}

There are many kind of teaching aids such as : chalkboard or whiteboard, map, overhead projector, computer, charts, calendars, flash chard, posters, slides, flip chart. Media is the plural form of medium. According to Celce Murcia ( $2001: 142$ ) "Media are tools or physical things used by the teacher to motivate the students by bringing a slice of real life into the classroom and presenting language in its more complete communication complex. The writer can say that media is important in teaching and learning English. On the one hand, media help the teacher to deliver the material being taught easier. On the other hand, the students can understand the material easily. Moreover, media is a good way to engage the students in learning English.

\subsection{The Concept of the English Writing Material}

Hutchinson and Waters (1987: 107-108) propose six criteria of good materials. First, materials provide a stimulus for learning. Good materials do not teach but encourage learners to learn. Second, materials help to organize the teaching learning process, by providing a path through the complex mass of the language to be learned. Good materials should provide clear and coherent unit structure which will help students in understanding the lesson through various tasks. Third, materials embody a view of the nature of language and learning. They should reflect about the learning process and content of the lessons. Forth, materials reflect the nature of the learning task. Materials should show some kind of tasks from the simple one to the most complex. Fifth, materials can have a very useful function in broadening the basis of teacher training by introducing teachers to new techniques. Finally, materials provide models at correct and appropriate language use. Giving authentic examples in each topic is very useful for the students. It will make them easier to understand what the purpose of the lessons.

It is known materials play important roles in the teaching and learning process. That is why materials have to be developed in the right organizations. Nunan (1991: 210) states that the way materials organized and presented as well as the types of the content and activities will help to shape the students "view of the target language. It is clearly shown that the way materials organized will give big effects to students ${ }^{\text {ee }}$ understanding.

Next, core standard and basic standard of English Curriculum of 2013 at Senior High School of Ministry of National Education No 24 year 2016 (2016 : 7) also compiles kinds of genre text in a different form namely; the following are the characteristics of each genre: for the ten grade students; descriptive text that describes the tourism places and historical places, narrative text that is relation to legend, whereas, for the eleven grade; analytical exposition text that is relation with real issue, biographical recount text and explanation text that is relation with natural and social phenomena , and explanation text that is relation with natural and social phenomena, procedure text and news item from newspaper, radio and television. 


\section{METHOD}

The research was conducted at senior high school that had implemented 2013 curriculum of Pesisir Selatan Regency. The data carried out 11 months from February until December 2017; they are the school year 2016/2017 of second semester (January - June 2017) and the school year 2017/2018 of the first semester (July December 2017). The finding was in relation to the research questions about how do the English teachers' management of the preparation of the lesson plan, the media and the English writing material in learning process of genre- based writing instruction in learning process at senior high school in 2013 curriculum of Pesisir Selatan Regency. The type of this research was qualitative evaluation in the form of Ethnography approach. There are three kinds of techniques in collecting the data, namely observation, interview and document analysis. The observation was conducted to understand and describe how the English teachers' management for the preparation in the teaching and learning process of genre - based writing instruction in 2013 curriculum at senior high school in Pesisir Selatan Regency can be able to match with the lesson plan prepared. Then, the interview was delivered to the participants of how the English teachers' management of the lesson plan, the media and the English material writing in the teaching and learning process of genre - based writing instruction in 2013 curriculum. These interviews that were supported by interview guide and field notes were done on different days, after interviewing the English teachers, the researcher also interviewed some students and one English supervisors to gain the valid data. Finally the researcher analyzed the document of the English teachers' preparation the lesson plan to help students learn English writing skill as suggested by genre-based curriculum

A qualitative evaluation research consists of some steps. The first is collecting the data. After the data have collected, it is analyzed. Next, the unimportant data is reduced. The data that is important is presented in the form of narration. The last is that the researcher has to draw conclusion based on the data obtained.

\section{FINDING AND DISCUSSION}

Based on the research that has been conducted at senior high school that had implemented 2013 curriculum of Pesisir Selatan Regency. Based on the researcher's observation, interview and document analysis, she found that the English teachers' management for the preparation of the lesson plan, the media and the English writing in teaching and learning process of genre - based writing instruction in the 2013 curriculum from ten informants of six senior high schools in Pesisir Selatan Regency hadn't been optimally.

First, the English teachers haven't prepared the lesson plan in teaching and learning process of genre based writing instruction in the 2013 curriculum well and properly as regulate at the minister of national education regulation no 22 year 2016 about process standard. It can be seen that there are ten English teachers as informants of this research, nevertheless only two informants that had prepared the lesson plan well and properly. It proved that the analyzing documents finding by using checklist observation of English teachers' lesson plan documents had got bad quality. In addition to the English teachers conducted the teaching and learning process of genre -based writing instruction didn't matched with the lesson plan prepared.

Second, the English teachers hadn't prepared the teaching aid or media in teaching and learning process of genre - based writing instruction in the 2013 curriculum optimally. It can be seen that there are ten English teachers as informants of this research, nevertheless only three informants that had prepared the media well and properly. This facts was proved from the observation finding of the seven informants from ten informants didn't used media in their teaching learning process of genre-based writing instruction in the classroom. They only used the English text book and white board as her/his teaching aids in teaching. They hadn't prepared media "the material power point, pictures and video as suggested by genre- based writing instruction. It was caused by the limited of in focus provided at school.

Finally, the English teachers English teachers have prepared the English writing material to help students learn English writing skill as suggested by genre-based writing instruction in the 2013 curriculum. Nevertheless, it is only adapted from the English text books or ready use books, most of them seldom create English writing materials by her/his self ; English module or diktat. It proved that all of the English teachers only took the English writing materials from the ready book or English text- book. Nevertheless, based on the the researcher's document analysis of the English text- book used, the English writing material had been highly functional, beneficial for the students' future life, easy to be applied, promote students to learn and practice the real use of the target language and matched with core competencies and basic competencies in the English syllabus as stated on minister of national education regulation no 21 year 2016 about content standard and no 24 about the core and basic competence standard in 2013 curriculum 


\section{CONCLUSION AND SUGGESTION}

It seems to the researcher that the analyzing finding of eight from ten English teachers' lesson plan documents had got bad quality. It was caused by the English teachers hadn't guided to the minister of national education regulation no 22 year 2016 about process standard, hadn't guided the Minister of National Education Regulation No 21 year 2016 about the content standard and the Minister of National Education Regulation No 24 year 2016 about the core competence and basic competence in the 2013 curriculum in designing or preparing the lesson plan. In addition to most of the English teachers conducted the teaching and learning process of genre -based writing instruction hadn't match with the lesson plan prepared. Then, there are ten English teachers as informants of this research, nevertheless only three informants that had prepared the media well and properly. This facts was proved from the observation finding in the classroom of the seven informants from ten informants didn't used media in teaching learning process of genre-based writing instruction. They only used the English text book and white board as her/his teaching aids in teaching. They hadn't prepared media "the material power point, pictures and video as suggested by genre- based writing instruction, it was caused by the limited of in focus provided at school. Next, Most of the English teachers had prepared the English writing materials plan to help students learn English writing skill as suggested by genre-based curriculum. Unfortunately, most English teachers only took the English writing materials from the ready book or English text- book, they didn't made the English writing material by themselves to enrich the material, for example, module and diktat. Fortunately, based on the the researcher's document analysis of the English text- book used, the English writing material had been highly functional, beneficial for the students' future life, easy to be applied, promote students to learn and practice the real use of the target language and matched with core competencies and basic competencies in the English syllabus as stated on minister of national education regulation no 21 year 2016 about content standard and no 24 about the core and basic competence standard in 2013 curriculum. Nevertheless, based on the application of the 2013 curriculum the teacher should have many sources of the subjects, then they also should be creative and innovative teachers, they can design the teaching and learning scenario based on genre- based writing instruction, then they also can create the material by themselves to enrich the students ' knowledge broadly. Furthermore, the English teachers should be able to design and use the teaching aids or media to motivate the students by bringing a slice of real life into the classroom.

\section{REFERENCES}

Alwasilah, A. C. (2001). Language, culture, and education: Portrait of contemporary Indonesia. Bandung: CV. Bawarshi, A. (2000). The genre function. College English, 62(3), 335-360. Bhatia, V. K. (1993). Analyzing genre: Language use in professional settings. New York: Longman.

Badger, R. and G. White. 2000. 'A process genre approach to teaching writing'. ELT Journal, 54/2: 157.

Brown, Douglas. 2001. Teaching by principles. An interactive approach to languagePedagogy. San Fransisco: Longman,149-163

Byram, M. (2004). Genre and genre-based teaching. The Routledge Encyclopedia of Language Teaching and Learning (pp. 234-237). London: Routledge.

Celce-Murcia, M. , Olshtain, E. 2001. Discourse and Context in Language Teaching: a Guide for Language Teachers. UK: Cambridge University Press.

Emilia, E. (2008). Pendekatan genre-based dalam Kurikulum Bahasa Inggris tahun 2006: Penelitian tindakan kelas di sebuah SMP Negeri di Bandung. Bandung: Jurusan Pendidika Bahasa Inggris FPBS UPI.

Emilia, E. (2010). Teaching writing: Developing critical learners. Bandung: Rizqi Press.

Gerot, Linda and Widnell, Peter. 1995. Making Sense of functional Grammar. Sydney: antipodean Educational Enterprises.

Halliday, M.A.K. 1978. Language as Social Semiotic. London: Edward Arnold

Hyland, K. (2004). Genre and Second Language Writing. Ann Arbor, MI: The University of Michigan Press. Hyland, K. (2007). Genre pedagogy: Language, literacy and L2 writing instruction. Journal of Second language Hegde, Tricia. 2000. Teaching and Learning in the Language Classroom. New York: Oxford University Press Hutchinson, T., and A. Waters. 1987. English for Specific Purpose. London: Cambridge University press.

Kim, Y., \& Kim, J. (2005). Teaching Korean university writing class: Balancing the process and the genre approach. Asian EFL Journal, pp / 68-89.

Nunan, D. 1991. A Process Genre Model for Teaching Writing. English Teaching Forum. Volume number 3. Paltridge, B. (2001). Genre and the language learning classroom. Ann Arbor: University of Michigan Press. Richards, Jack C, and Willy A. Renandya. 1992. Methodology in teaching and Anthology 
of Current Practice. London. Cambridge University Press. Rinvolucri, Mario. 1996. Letter to Craig Thaine. The Teacher Trainer 10/2. ,7. Retrieved

from: ttedsig.iatefl.org/resources/articles/13.doc. Date: 17 febrero 2009,10:00 a.m.Scrivener, Jim. 2005.

Learning teaching2nd ed.

Swales, J. M. (1990). Genre analysis: English in academic and research settings. Cambridge, UK: Cambridge University Press.

The Ministry of Education and Culture Republic of Indonesia Regulation (2016). Nomor 20 : standar isi pendidikan.Jakarta: 2016

The Ministry of Education and Culture Republic of Indonesia Regulation (2016). Nomor 22 : standar proses pendidikan. Jakarta: 2016

The Ministry of Education and Culture Republic of Indonesia Regulation (2016). Nomor 24 : kompetensi inti dan kompetensi dasar untuk tingkat SD, SMP dan SMA. Jakarta: 2016

Undang - undang Nomor 30 Tahun 2003 tentang Sistem Pendidikan Nasional. Jakarta: 2003

Yan, G. A. (2005). Process-genre model for teaching writing. English Teaching Forum, 43 (3): pp. 18-26, (Online), accessed on (http://eca.state.gove/forum/vols/vol43/no3/p18.html), accessed on February, 2013. 